\title{
PENERAPAN HIDS (HOST INTRUSION DETECTION SYSTEM) DALAM MEMBANGUN KONFIGURASI FIREWALL SECARA DINAMIK
}

\author{
Alfian Firdaus, Haruno Sajati, Yuliani Indrianingsih \\ Teknik Informatika STTA Yogyakarta \\ Informatika@stta.ac.id
}

\begin{abstract}
Development of information technology and computer networks in particular its services on the one hand facilitate the work of human beings, but as the very widespread use of the internet, the security level of digital data has become more vulnerable to exploitation. The problem arises when the attacks happened on a computer network in a relatively fast, so that an administrator must always keep an eye on the computer network security. Limitations of an administrator is exactly what underlies the creation of a system capable of detecting and prevention of these attacks, so the time efficiency can be actually implemented. The system is built to prevent attacks on computer networks such as port scanning, ftp, ssh and telnet brute force. This system will analyze the number of errors that occur on login these services, and makes a decision system if the login error exceeds the tolerance of an administrator. If the number of errors exceeds the tolerance, it will automatically create the firewall rules in a very short duration is one minute, so the system is able to prevent the attacks which happened in a very quick time.
\end{abstract}

Keyword: IDS, Port Scanning, ftp, ssh and telnet brute force.

\section{LATAR BELAKANG MASALAH}

Mengingat beban pekerjan seorang network administrator yang besar dan luas, sangat tidak mungkin seorang network administrator untuk selalu update setiap waktu terhadap serangan-serangan baru dan dengan singkat membuat signature untuk serangan baru tersebut. Maka muncullah ide bagaimana membuat suatu sistem deteksi intrusi yang dapat mengenali pola serangan baru dari serangan-serangan lama yang sudah ada pada aturan pada firewall dan secara otomatis membuat signaturee untuk serangan tersebut dan menambahkannya ke dalam rule yang ada pada router firezoall.

\section{LANDASAN TEORI}

\section{HIDS (Intrusion Detection System)}

Host Intrusion Detection System dapat didefinisikan sebagai suatu sistem yang mampu mendeteksi aktifitas yang mencurigakan dalam sebuah jaringan yang menuju ke perangkat komputer tersebut, HIDS mampu melakukan pedeteksian dengan cara melakukan pemantauan terhadap lalu lintas (traffic) yang keluar maupun masuk dalam sebuah sistem atau jaringan ataupun mendeteksi berdasarkam perbandingan pola lalu lintas jaringan normal yang ada dan kemudian membandingkannya dengan lalu lintas yang ada pada jaringan komputer tersebut. 


\section{Komponen-komponen HIDS}

a. IDS Rule. Merupakan database yang berisi pola-pola serangan berupa signature jenisjenis serangan. Rule IDS ini, harus di update secara rutin sehingga IDS mampu mendeteksi jenis serangan baru.

b. IDS Engine. Merupakan program yang berjalan sebagai proses yang selalu bekerja untuk membaca paket data dan kemudian membandingkan dengan rule IDS.

c. IDS Alert. Merupakan catatan serangan pada deteksi penyusupan, jika IDS engine mengukumi paket daya yang lewat sebagai serangan, maka IDS engine akan mengirimkan alert berupa log file. Untuk kebutuhan analisa, alert dapat disimpan di dalam database, sebagai contoh BASE (Basic Analysis and Securtiy Engine) yang berfungsi untuk mencari dan mengolah database dari alert network security yang dibangkitkan oleh perangkat lunak pendeteksi intrusi (IDS).

\section{Jenis Serangan}

Jenis Serangan yang dibahas dalam pengujian ini adalah sebagai berikut :
a. Port Scan
b. FTP Brute Force
c. SSH Brute Force
d. TELNET Brute Force

\section{Filter}

Router akan membuat aturan firewall untuk menentukan apakah hendak meneruskan paket yang masuk atau menghentikannya. Ada 3 macam chain yang digunakan dalam tabel filter ini yaitu:

a. Input Chain, yaitu penyaringan traffic yang menuju ke sebuah mesin firewall atau router.

b. Output Chain, yaitu penyaringan traffic dari mesin firewall menuju ke perangkat luar

c. Forward Chain, yaitu penyaringan traffic untuk meneruskan traffic ataupun request dari dan ke perangkat lain yang melewati firewall atau router.

\section{PERANCANGAN}

Untuk keperluan analisa serangan yang terjadi, maka diperlukan tabel pendukung yang ditambahkan pada database snort, masing-masing tabel memiliki kegunaan tersendiri. Adapun tabel yang akan dibuat antara lain :

\section{Pembuatan Tabel Pengamatan}

a. Tabel xsshtel

Tabel xsshtel adalan tabel yang ditambahkan untuk keperluan penampungan record kesalahan otentikasi terhadap layanan FTP, SSH dan TELNET dengan menggunakan serangan brute force. Data yang terdapat dalam tabel xsshtel merupakan data yang berisi keseluruhan hasil dari pengambilan record kesalahan otentikasi menggunakan fungsi grep pada file auth.log untuk SSH dan TELNET dan file vsftpd.log untuk FTP, sehingga record yang ada pada tabel xsshtel sangat banyak dan masih terdapat banyak record data yang sama atau duplicate record

b. Tabel xfilter

Tabel xfilter berfungsi untuk menampung record yang telah diolah berdasarkan record yang ada pada tabel xsshtel, pengolahan yang dilakukan yaitu mengelompokkan record berdasarkan sig_name (signature name) dan ip_src, sehingga record yang dihasilkan yaitu 
jumlah total dari masing-masing record berdasarkan sig_name dan ip_src tersebut. Jumlah total ini yang nantinya akan digunakan untuk penentuan apakah kesalahan otentikasi tersebut akan dirubah menjadi firewall atau tidak.

c. Tabel temp_ip

Tabel temp_ip merupakan tabel yang dibuat secara manual pada database snort untuk keperluan menampung record yang telah siap untuk dieksekusi menjadi aturan firewall pada router mikrotik. Pada tabel ini terdapat suatu field yang menjadi patokan untuk pengeksekusian record menjadi aturan pada firewall, yaitu field executed. field executed tersebut berisi dua nilai string yaitu "No" dan "Yes", hal tersebut berfungsi sebagai penanda bahwa baris record tersebut telah dieksekusi atau belum.

\section{Mekanisme Penyerangan}

\section{a. Port Scan}

Mekanisme penyerangan dengan terhadap port scanning akan dilakukan menggunakan perangkat lunak nmap. Yaitu dengan memberikan perintah nmap - $A$ ip_address pada nmap tersebut, penggunakan fitur " $-A$ " tersebut dimaksudkan untuk melakukan pemindaian (scanning) secara agresif terhadap perangkat komputer server.

\section{b. FTP Brute Force}

Serangan brute force terhadap layanan FTP dapat dilakukan menggunakan perangkat lunak hydra. Pada perancangan ini port yang digunakan untuk layanan FTP masih secara default yaitu pada port 21. Sehingga perintah pada hydra yang akan digunakan yaitu \# hydra $-L$ user.txt $-P$ pass.txt ip_server ftp. File user.txt dan pass.txt adalah file yang berisi kumpulan kata atau kamus kata yang akan digunakan penyerang untuk melakukan brute force.

c. SSH Brute Force

Serangan terhadap layanan SSH menggunakan perangkat lunak hydra dengan perintah \#hydra -L user.txt -P pass.txt ip_server ssh. Untuk menampilkan pencocokan kemungkinan kombinasi username dan atau password pada layanan SSH, hydra memiliki fitur " $-V$ ", sehingga penulisan perintah menjadi \#hydra-V -L user.txt -P pass.txt ip_server ssh.

\section{d. TELNET Brute Force}

Mekanisme serangan yang akan dirancang untuk serangan terhadap TELNET menggunakan perangat lunak hydra yaitu dengan memberikan perintah \#\#hydra - L user.txt $-P$ pass.txt ip_server telnet, yang secara default akan tertuju pada port 23. Apabila administrator mengganti port pada layanan tertentu, maka dengan hydra dapat menuliskan perintah \#hydra -L user.txt -P pass.txt -s port ip_server ssh.

\section{Mekanisme Pendeteksian}

\section{a. Port Scan}

Mekanisme pendeteksian serangan menggunakan port scanning dapat dideteksi dengan menganalisa database snort pada tabel acid_event, untuk port scanning akan memiliki signature name "(port scan) Open Port". Signature name atau tanda peringatan tersebut dapat dimanfaatkan untuk dijadikan sebuah aturan pemblokiran pada firewall.

\section{b. SSH dan TELNET Brute Force}

Untuk serangan terhadap layanan SSH dan TELNET dapat memanfaatkan file pencatat kejadian otentikasi pada sistem operasi linux, yaitu pada file auth.log yang berada pada direktori foar/log/auth.log. File auth.log berisi seluruh kejadian login baik sukses ataupun gagal, record yang dimanfaatkan yaitu record kesalahan login yang berulang-ulang dan terjadi dari 
satu ip address yang sama. Pengambilan record pada file tersebut dapat menggunakan fungsi grep yang terdapat pada sistem operasi linux dengan menambahkan kata kunci untuk menyaring record yang diperlukan untuk penambahan aturan firewall tersebut.

Untuk layanan SSH, kata kunci pengambilan record kesalahan pada file auth.log yaitu "Failed" dan "ssh". Pengambilan record menggunakan fungsi grep dilakukan dengan menuliskan perintah pada terminal (console) seperti \#grep Failed /oar/log/auth.log I grep ssh. Sedangkan untuk pengambilan record TELNET menggunakan kata kunci "failure" dan "login" yaitu dengan menuliskan perintah \#grep failure foar/log/auth.log I grep login.

c. FTP Brute Force

Untuk serangan terhadap layanan FTP dapat memanfaatkan file vsftpd.log yang berada pada direktori foar/log/osftpd.log dengan kata kunci "FAIL". Sehingga perintah grep yang digunakan yaitu \#grep FAIL/var/log/osftpd.log.

\section{Mekanisme Pertahanan}

a. Port Scan

Pertahanan yang dilakukan terhadap serangan port scanning yaitu dengan mengambil record pada database snort yaitu pada tabel acid_event dengan kata kunci "(port scan) Port Open". Record yang didapat tersebut selanjutnya akan dimasukkan (insert) kedalam tabel temp_ip untuk menunggu dieksekusi menjadi sebuah aturan pada firewall pada saat program dijalankan secara terjadwal.

b. FTP, SSH dan TELNET Brute Force

Pencegahan terhadap serangan dilakukan dengan menganlisa tabel xsshtel, yaitu mengelompokkan kumpulan record-record tersebut berdasarkan jenis serangan (signature name) dan ip address untuk selanjutnya akan dimasukkan (insert) kedalam tabel xfilter. Berdasarkan tabel xfilter akan ditentukan apakah record dari jenis serangan (signature name) dan ip address yang sama melebihi batas toleransi kesalahan, dalam pengujian ini diberikan toleransi sebanyak tiga kali kesalahan login, jika record kesalahan tersebut melebihi tiga, maka record tersebut akan dimasukkan (insert) kedalam tabel temp_ip untuk menunggu dieksekusi menjadi sebuah aturan pada firewall pada saat program berjalan.

\section{IMPLEMENTASI}

\section{Uji Serangan FTP Brute Force}

Serangan terhadap layanan FTP pada sebuah perangkat tidak jauh berbeda dengan serangan terhadap layanan SSH, perbedaan hanya terdapat pada default port untuk FTP yang berbeda dengan SSH yaitu FTP memiliki port 21, penggunaan port pada layanan SSH, FTP maupun TELNET dapat disesuaikan atau diganti oleh administrator jaringan tersebut, sehingga menyulitkan penyerangan untuk mengakses port pada layanan-layanan tersebut. Adapun perintah untuk melakukan serangan terhadap layanan FTP menggunakan terminal (console) adalah sebagai berikut \#hydra-L user.txt -P pass.txt ip_tujuan FTP.

\section{Uji Serangan SSH Brute Force}

Serangan terhadap layanan SSH yang secara default pada port 22 yaitu dengan menggunakan perangkat lunak pencocokan kata (Dictionary Attack) THC-Hydra, perangkat lunak hydra ini akan melakukan pencocokan username dan atau password berdasarkan kamus kata yang telah dipersiapkan terlebih dahulu. Proses ini berjalan selama port SSH tetap terbuka dan diberikan izin untuk mengakses alamat ip yang dituju. Melakukan serangan 
dengan menggunakan hydra melalui terminal cukup mudah, yaitu dengan menuliskan perintah hydra -L user.txt -P pass.txt ip_tujuan SSH, namun apabila penyerang terlebih dulu mengetahui username dari layanan yang akan diserang, maka dapat menuliskan perintah pada terminal seperti \# hydra-l admin -P pass.txt ip_tujuan SSH.

\section{Uji Serangan TELNET Brute Force}

TELNET merupakan layanan yang digunakan untuk melakukan pertukaran atau pengaksesan file dari jarak jauh (remote) pada suatu perangkat. Untuk login secara normal pada layanan TELNET dapat menggunakan perintah pada console yaitu \# sudo TELNET ip_address. Serangan pada layanan TELNET tidak jauh berbeda dengan serangan terhadap layanan SSH dan FTP, melakukan serangan dapat dilakukan dengan mengetikkan perintah diterminal hydra -L user.txt -P pass.txt ip_tujuan TELNET.

\section{Uji Serangan Port Scanning (NMAP)}

Penggunaan fungsi -A pada nmap berguna untuk melakukan scanning port secara aggressive, penggunaan fungsi ini akan menghasilkan informasi yang terperinci mengenai alamat ip yang dituju, informasi yang dihasilkan seperti daftar port-port yang aktif pada perangkat tersebut, Operating System, Computer-Name, OS finger print, dan lain-lain. Snort akan mencatat aktifitas tersebut ke dalam database snort untuk selanjutnya diperoses. Snort akan mencatat beberapa entitas dari data tersebut seperti sig_name, timestamp, ip_src, ip_dst. Untuk aktifitas seperti port scanning akan memiliki signature name yang unik yaitu "port scan", yang tidak sama dengan aktifitas lainnya yang dicatat oleh snort. Signature name tersebut dapat dimanfaatkan sebagai kata kunci untuk memilih record port scanning pada database snort.

\section{KESIMPULAN DAN SARAN}

\section{Kesimpulan}

a. Penerapan aturan firewall dapat digunakan secara otomatis berdasarkan jenis dan jumlah serangan yang terjadi dengan menggunakan nmap dan hydra sebanyak lebih dari tiga kali.

b. Memanfaatkan IDS Snort, auth.log dan vsftpd.log sebagai pendeteksian serangan yang menuju ke server.

c. Sistem otomatisasi penambahan aturan firewall ini cukup handal dari sisi keamanan jaringan, dikarenakan sistem ini dieksekusi dalam waktu yang sesingkat-singkatnya yaitu dalam interval waktu 1 menit, sehingga intruder akan sulit untuk melewati sistem ini

\section{Saran}

a. Sistem dapat dikembangkan menjadi sebuah sistem yang user friendly dari sisi administrator, sehingga hasil penambahan aturan firewall yang telah ditambahkan dapat disajikan dalam bentuk informasi dan sistem bisa dikendalikan dari interface yang tersedia dengan web base.

b. Sistem dapat dikembangkan dengan menambah jumlah serangan yang mampu di deteksi dan di cegah oleh sistem, karena saat ini sistem hanya membahas tentang empat jenis serangan terhadap jaringan komputer. 


\section{DAFTAR PUSTAKA}

Cartealy, Imam. 2013. Linux Networking (Ubuntu, Kubuntu, Debian, dll). Jasakom.

Raharjo, Budi. 2011. Belajar otodidak PEMROGRAMAN WEB dengan PHP + ORACLE. Bandung : Informatika Bandung.

Riyanto. 2010. Sistem Informasi Penjualan dengan PHP dan MySQL. Yogyakarta : GAVA MEDIA Sulistiyani, Sri. Administrasi jaringan dengan Linux ubuntu. 2011. Yogyakarta : ANDI.

Tuxkeren, Athailah. 2013 . Ubuntu Server Panduan Singkat \& Cepat. Jasakom.

Zam, Efvy. 2012. Wireless Hacking. Jakarta : PT Elex Media Komputindo 